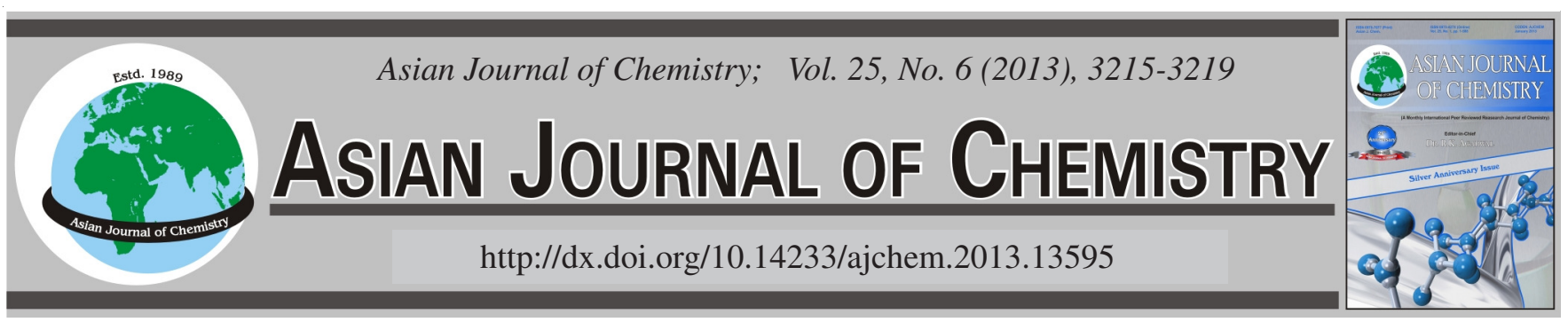

\title{
Constituents, Antimicrobial and Antioxidant Activities of Pulicaria gnaphalodes (Vent.) Bioss. Volatile Oil from Iran
}

\author{
M. KAZEMI ${ }^{1, *}$, G.R. NAGAFI ${ }^{1}$ and A. AzAD ${ }^{2}$
}

${ }^{1}$ Department of Applied Chemistry, Qom Branch, Islamic Azad University, Qom, Iran

${ }^{2}$ Department of Applied Chemistry, Saveh Branch, Islamic Azad University, Saveh, Iran

*Corresponding author: E-mail: smkazemit@yahoo.com

(Received: 15 February 2012;

Accepted: 14 December 2012)

AJC-12551

\begin{abstract}
The water distilled essential oil of the aerial parts of $P$. gnaphalodes from Qom area of Iran was analyzed by GC-FID and GC/MS methods. Eighty-eight compounds, accounting for $89 \%$ of the total oil, were indentified. The main components of the oil were myrtenol $(13.2 \%)$, citronellol (9.0\%), (E)-nuciferol (5.2\%), shiromoll (5.1\%), geraniol (5.1\%) and $\alpha$-pinene (5.0\%). The oil was rich in regards to oxygenated monoterpenes $(48.8 \%)$. The antimicrobial activity of the oil was measured by a disc diffusion method. The oil has shown maximum zone of inhibition against Candida albicans $(23 \pm 1.2 \mathrm{~mm})$ with a value higher than that of fluconazol $(18.0 \pm 0.3 \mathrm{~mm})$. The oil antioxidant activities were valued by DPPH assay and $\beta$-carotene-linoleic acid assays. The essential oil strongly reduced the concentration of DPPH free radical $(36.0 \pm 1.3 \%)$, with an efficacy higher than that of trolox $(33.0 \pm 0.5 \%)$. The oil had high inhibition against BHD standard in $\beta$-carotene bleaching test.
\end{abstract}

Key Words: Pulicaria gnaphalodes, Essential oil composition, Myrtenol, Citronellol, Shiromoll, Geraniol, $\alpha$-Pinene.

\section{INTRODUCTION}

The relatively larg Pulicaria genus belongs to the plant family asteraceae (compositae) ${ }^{1}$. This genus is represented in the flora of Iran by five species ${ }^{2}$. Some Pulicaria species are useful in traditional medicine for the treatment of a variety of diseases and complaints. Traditionally, the roots of $P$. odora are still used for their antiinflammatory properties ${ }^{3}$. P. undulata is a medicinal plant used by people of Southern Egypt and Saudi Arabia to treat inflammation ${ }^{4}$. It is used also as an insect repellent ${ }^{5}$. Various medical activities such as antibacterial, antifungal, antioxidant, antiinflammatory and anticholinesterase, have been reported from Pulicaria genus ${ }^{4,6-9} . P$. gnaphalodes has been investigated chemically; a new clerodane lactone, which is closely related to hardwickiic acid, has been reported from the aerial parts of this plant from $\operatorname{Iran}^{10}$. Likewise, from areal parts extract of $P$. gnaphalodes from Iran have been analyzed for exudate flavonoids ${ }^{11}$. It was shown to accumulate mostly 6-methoxylated flavonols and flavones as external aglycones. In another report, from chloroform extract of $P$. gnaphalodes, flavonoids, sesquiterpenoid, sterol, benzoic acid derivaties and fatty acid were obtained ${ }^{12}$. The structures were elucidated the aid of NMR spectroscopy. In other report on extract of $P$. gnaphalodes, a new sesquiterpene-dimer of guaiane class named as gnapholide and anabsinthin of the same skeleton were identified ${ }^{13}$. The structures of both the compounds were elucidated with the aid of spectroscopic techniques including ${ }^{2} \mathrm{D}$ NMR. In recent report, five compounds including one phenolic acid (salicylic acid), two clerodane diterpenoids (salvifolin and salvicin) and two flavonoids (pulicarin and giperoside) were isolated from alcoholic extract of the aerial parts of endemic $P$. gnaphalodes from central Asia $^{14}$.

Also, in previous studies about the essential oils of other Pulicaria species, the chemical composition of the oil from aerial parts of $P$. dysenterica, growing wild in $\operatorname{Iran}^{15}$ and Greece $^{16}$, was determined by GC and GC/MS. The main components of the Iranian sample oil were ar-curcumene (28.3\%), epi- $\alpha$-cadinol (16.4\%) and (E)-coniferyl alcohol $(11.0 \%)$ while the main components in two Greek oil samples were (Z)-nerolidol (11.2\%), caryophyllene oxide (9.1\%) and (E)-nerolidol (6.6\%) (sample A) and $\beta$-caryophyllene (12.8\%), caryophyllene oxide $(12.8 \%)$ and (E)-nerolidol $(6.9 \%)$ (sample B). Although, in the literature, to our best of knowledge no report has observed about of antioxidant activity of Pulicaria essential oil also numerous another reports have appeared on the essential oils and its antimicrobial activity of different species of Pulicaria ${ }^{17-23}$, but in the present study, the antimicrobial and antioxidant activities of the essential oil of P. gnaphalodes from Qom area of Iran are reported. 


\section{EXPERIMENTAL}

The aerial parts of $P$. gnaphalodes were collected during the flowering stage in Qom area, province of Qom, Iran, in August 2010. Voucher specimens have been deposited at the Herbarium of the Research Institute of Forests and Rangelands, Tehran, Iran.

Isolation of the oil: The aerial parts $(152.0 \mathrm{~g})$ of $P$. gnaphalodes of the plant were subjected separately to hydrodistillation using a Clevenger-type apparatus for $3 \mathrm{~h}$. After decanting and drying over anhydrous sodium sulfate, the corresponding yellowish coloured oils were recovered in yields of $0.1 \%(w / w)$, respectively. The sample were then kept in bottles covered in aluminium foil at $4{ }^{\circ} \mathrm{C}$ to prevent the negative effect of light, especially direct sunlight.

Gas chromatography-flame ionization detector analysis was performed on a Shimadzu 15A gas chromatograph equipped with a split/splitless (ratio 1:30), injector $\left(250^{\circ} \mathrm{C}\right.$ ) and a flame ionization detector $\left(250^{\circ} \mathrm{C}\right) . \mathrm{N}_{2}$ was used as carrier gas $(1 \mathrm{~mL} /$ $\mathrm{min})$ and the capillary column used was DB-5 (50 $\mathrm{m} \times 0.2 \mathrm{~mm}$, film thickness $0.32 \mu \mathrm{m})$. The column temperature was kept at $60{ }^{\circ} \mathrm{C}$ for $3 \mathrm{~min}$ and then heated to $220^{\circ} \mathrm{C}$ with a $5^{\circ} \mathrm{C} / \mathrm{min}$ rate and kept constant at $220{ }^{\circ} \mathrm{C}$ for $5 \mathrm{~min}$. Relative percentage amounts were calculated from peak area using a Shimadzu C-R4A chromatopac without the use of correction factors.

Analysis was performed using a Hewlett- Packard 5973 with a HP-5MS column $(30 \mathrm{~m} \times 0.25 \mathrm{~mm}$, film thickness 0.25 $\mu \mathrm{m})$. The column temperature was kept at $60^{\circ} \mathrm{C}$ for $3 \mathrm{~min}$ and programmed to $220^{\circ} \mathrm{C}$ at a rate of $5^{\circ} \mathrm{C} / \mathrm{min}$ and kept constant at $220^{\circ} \mathrm{C}$ for $5 \mathrm{~min}$. The flow rate of helium as carrier gas was ( $1 \mathrm{~mL} / \mathrm{min}$ ). MS were taken at $70 \mathrm{eV}$, mass range, 30 to 350 amu and scan time 2 scans/sec.

Identification of components: The compounds were identified by comparison of their mass spectra with the Wiley library or with published mass spectra ${ }^{15}$. The identifications were confirmed by comparison of KI from HP-5MS column with those reported in the NIST liberary and the Pherobase database $^{24,25}$. The Kovats indices for all the components were determined according to the Van Den Dool method, using $n$-alkanes as standards ${ }^{26}$.

Microorganisms: The bacteria included Escherichia coli (ATCC 1399) and Staphylococcus aureus (ATCC 1431) and fungi included Candida albicans (ATCC 5027). The microorganisms were obtained from the Research Center of Science and Industry, Tehran, Iran.

Antimicrobial tests: The antimicrobial activity of the essential oil was evaluated by a disc diffusion method using Mueller-Hinton and Sabouraud Dextrose agar respectively ${ }^{27,28}$. A suspension of the tested microorganism $(0.1 \mathrm{~mL}$ of a suspension of the tested microorganisms, containing $1.5 \times 10^{8}$ (CFU/ $\mathrm{mL}$ ) was spread on the solid media plates. Mueller-Hinton and Sabouraud Dextrose agar sterilized in a flask and cooled to 45$50{ }^{\circ} \mathrm{C}$ were distributed to sterilized Petri dishes with a diameter of $9 \mathrm{~cm}(15 \mathrm{~mL})$. A serial dilution of the oil was prepared in Mueller-Hinton and Sabouraud Dextrose Broth for bacteria and fungi respectively. The filter paper discs (6 $\mathrm{mm}$ in diameter) were individually impregnated with $15 \mu \mathrm{L}$ of the $P$. gnaphalodes essential oil and then placed onto the agar plates, which had previously been inoculated with the tested microorganisms. The plates were inoculated with bacteria incubated at $37^{\circ} \mathrm{C}$ for $24 \mathrm{~h}$ and at $28^{\circ} \mathrm{C}$ for $72 \mathrm{~h}$ for the fungal strains. Ethanol $(95 \%)$ was used as a negative control in all the plates while ampicillin (10 $\mathrm{mg} /$ disc), gentamicin (10 mg/disc) for bacteria and fluconazol (20 mg/disc) were used as positive controls. The diameters of the inhibition zones were measured in millimetres.

Radical-scavenging capacity (DPPH assay) of the oil: The hydrogen atom or electron donation abilities of the essential oil were measured from the bleaching of the purple-coloured methanol solution of 2,2-diphenylpicrylhydrazyl (DPPH). This spectrophotometric assay uses the stable radical DPPH as a reagent ${ }^{29}$. In order to find out the effective dose of oil, different concentrations $(0,5,10$ and $20 \% \mathrm{v} / \mathrm{v}$ in methanol) were added to DPPH reaction mixture and the concentration-dependent inhibition in DPPH radical scavenging capacity was recorded (Data not shown). Based on this, further experiments were carried out with $20 \%(\mathrm{v} / \mathrm{v})$ of the oil. Then, $50 \mu \mathrm{L}$ of the essential oil in methanol were added to $5 \mathrm{~mL}$ of DPPH solution (0.004 \% DPPH in methanol). Trolox (1.00 mM, $0.500 \mathrm{mM}$ and $0.250 \mathrm{mM}$ ), a stable antioxidant, was used as reference. After incubation for $0.5 \mathrm{~h}$ at room temperature, the absorbance was read against the blank at $517 \mathrm{~nm}$. The following formula was used to estimate the inhibitory effects of the oil extract in percent $(\mathrm{I} \%)$ : I \% = (A blank - A sample/A blank $) \times 100$. Where, a blank is the absorbance of the control reagent (containing all reagents except the test compound) and A sample is the absorbance of the test compound. All the assays were carried out in triplicate.

$\boldsymbol{\beta}$-Carotene-linoleic acid assay of the oil: Antioxidant activity of the essential oil was determined using the $\beta$-carotene bleaching test as described by Taga et al. ${ }^{30}$. Approximately $10 \mathrm{mg}$ of $\beta$-carotene (type I synthetic) was dissolved in 10 $\mathrm{mL}$ of chloroform. Two milliliters of the carotene-chloroform solution was pipetted into a boiling flask containing $20 \mathrm{mg}$ linoleic acid and $200 \mathrm{mg}$ Tween 40 . Chloroform was removed using a rotary evaporator at $40{ }^{\circ} \mathrm{C}$ for $5 \mathrm{~min}$. Then, the residue was dissolved in $50 \mathrm{~mL}$ of distilled slowly with vigorous agitation, to form an emulsion. Five milliliters of the emulsion were added to a tube containing $0.2 \mathrm{~mL}$ of essential oil solution, prepared according to Choi et $a l .^{31}$. The absorbance was immediately measured at $470 \mathrm{~nm}$ against a blank, consisting of an emulsion without $\beta$-carotene. The tubes were placed in a water bath at $50{ }^{\circ} \mathrm{C}$ and the oxidation of the emulsion was monitored spectrophotometrically by measuring absorbance at $470 \mathrm{~nm}$ over a $60 \mathrm{~min}$. A sample containing $0.2 \mathrm{~mL}$ of ethanol instead of essential oils was used as control. Butylated hydroxyl toluene (BHT), a stable antioxidant, was used as a synthetic reference. The antioxidant activity was expressed as inhibition percentage with reference to the control after 60 min of incubation, using the following equation: $\mathrm{AA}=100$ (DRC-DRS)/DRC, where AA = antioxidant activity, DRC = degradation rate of the control $=[\ln (\mathrm{a} / \mathrm{b}) / 60], \mathrm{DRS}=$ degradation rate in presence of the sample $=[\ln (\mathrm{a} / \mathrm{b}) / 60], \mathrm{a}=\mathrm{absor}-$ bance at time $0, b=$ absorbance at $60 \mathrm{~min}$.

\section{RESULTS AND DISCUSSION}

The eseential oil obtained from aerial parts of $P$. gnaphalodes are listed in Table-1 in which the percentage and retention indices of the components are given. At it is shown 
from Table-1, analysis of the aerial parts oil of $P$. gnaphalodes resulted in the identification of 88 constituents, representing $89.0 \%$ of the oil. The main components of the oil were myrtenol (13.2\%), citronellol (9.0\%), (E)-nuciferol (5.2\%), shiromoll $(5.1 \%)$, geraniol $(5.1 \%)$ and $\alpha$-pinene $(5.0 \%)$. The aerial parts of $P$. gnaphalodes oil were found to be rich in regards to oxygenated monoterpenes $(48.8 \%)$ while hydrocarbon monoterpenes $(5.2 \%)$ and sesquiterpenes $(1.6 \%)$ were the minor fractions of terpenoides. Aromatic compounds contained $(17.0 \%)$ phenolic derivatives was obtained as antioxidant agents. Previously, some new cadinene derivatives such as 1,8-oxidocadin-4-ene, 1(10),4-cadinadien-8a-ol, 4,10(14)cadinadien-8-o1 and 4,10(14)-muuroladien-8-o1 were isolated from $P$. gnaphalodes essential oil ${ }^{17}$. Also, the oil of $P$. gnaphalodes from Tehran area was investigated ${ }^{18}$. The oil contained about $65 \%$ monoterpenes, with $\alpha$-pinene (34\%) and 1,8-cineole (12\%) as main constituenets and ca. $30 \%$ sesquiterpenes, having a cadinane or bisabolane skeleton. Some compounds are observed in present research but major components are difference in three works. Pinane drivatives were also found in the oils of many Pulicaria species, especially $\alpha$-pinene in the oils of $P$. laciniata ${ }^{19}$ and $P$. undulata ${ }^{20}$. Cadinane derivatives the minor component of the oil of $P$. gnaphalodes, is also characteristic of the oils of $P$. dysenterica ${ }^{15}$, $P$. arabica $^{22}$ and $P$. glutinosa $a^{23}$.

\begin{tabular}{|c|c|c|c|c|}
\hline \multicolumn{5}{|c|}{$\begin{array}{l}\text { TABLE-1 } \\
\text { PERCENTAGE COMPOSITION OF THE AERIAL } \\
\text { PARTS OF Pulicaria gnaphalodes OIL }\end{array}$} \\
\hline & Compound & $\mathrm{KI}^{\mathrm{a}}$ & $\mathrm{KI}^{\mathrm{b}}$ & $\begin{array}{c}(\% \\
w / w)^{c}\end{array}$ \\
\hline 1 & 2-(E)-Hexenal & 855 & 854 & 0.2 \\
\hline 2 & $\alpha$-Pinene & 939 & 936 & 5.0 \\
\hline 3 & 2-Pentyl furan & 992 & 988 & 0.1 \\
\hline 4 & Yomogi alcohol & 999 & 996 & 0.2 \\
\hline 5 & $p$-Cymene & 1025 & 1019 & 0.2 \\
\hline 6 & Limonen & 1029 & 1024 & 0.1 \\
\hline 7 & 1,8-Cineole & 1031 & 1026 & 1.0 \\
\hline 8 & Santolina alcohol & 1040 & 1033 & 0.1 \\
\hline 9 & $\gamma$-Terpinene & 1060 & 1055 & 0.1 \\
\hline 10 & Artemisia alcohol & 1084 & 1080 & 0.1 \\
\hline 11 & Linalool & 1097 & 1096 & 0.6 \\
\hline 12 & Filifolone & 1103 & 1097 & 0.1 \\
\hline 13 & $n$-Nonanal & 1101 & 1099 & 0.2 \\
\hline 14 & trans-Pinocarveol & 1139 & 1143 & 0.2 \\
\hline 15 & Comphor & 1146 & 1149 & 0.4 \\
\hline 16 & Isopulegol & 1150 & 1152 & 0.2 \\
\hline 17 & (Z)-Tagetone & 1152 & 1157 & 0.2 \\
\hline 18 & Nerol oxide & 1165 & 1158 & 0.3 \\
\hline 19 & $p$-Mentha-1,5-dien-8-ol & 1179 & 1170 & 0.3 \\
\hline 20 & Borneol & 1187 & 1169 & 0.6 \\
\hline 21 & Terpinen-4-ol & 1193 & 1177 & 0.4 \\
\hline 22 & $\alpha$-Terpineol & 1189 & 1189 & 0.2 \\
\hline 23 & Myrtenol & 1196 & 1180 & 13.2 \\
\hline 24 & $\gamma$-Terpineol & 1195 & 1199 & 0.2 \\
\hline 25 & $\gamma$-Campholenyl formate & 1202 & 1200 & 0.4 \\
\hline 26 & trans-Carveol & 1215 & 1217 & 0.3 \\
\hline 27 & Citronellol & 1227 & 1226 & 9.0 \\
\hline 28 & Thymyl methyl ether & 1232 & 1235 & 0.2 \\
\hline 29 & (Z)-Citral & 1238 & 1238 & 1.4 \\
\hline 30 & cis-Chrysanthenyl acetate & 1250 & 1253 & 1.2 \\
\hline 31 & Geraniol & 1254 & 1253 & 5.1 \\
\hline 32 & cis-Myrtanol & 1251 & 1254 & 0.5 \\
\hline
\end{tabular}

\begin{tabular}{|c|c|c|c|c|}
\hline & Compound & $\mathrm{KI}^{\mathrm{a}}$ & $\mathrm{KI}^{\mathrm{b}}$ & $\begin{array}{c}(\% \\
w / w)^{\mathrm{c}}\end{array}$ \\
\hline 33 & $(E)$-Citral & 1268 & 1267 & 1.8 \\
\hline 34 & Citronellyl formate & 1272 & 1275 & 0.2 \\
\hline 35 & 3,7-Dimethyl-(E)-2,6-Octadien-1-ol & 1278 & 1277 & 0.2 \\
\hline 36 & Thymol & 1289 & 1290 & 1.1 \\
\hline 37 & Geranyl formate & 1299 & 1298 & 0.1 \\
\hline 38 & Myrtenyl acetate & 1325 & 1327 & 4.1 \\
\hline 39 & Citronellyl acetate & 1351 & 1353 & 1.0 \\
\hline 40 & Neric acid & 1354 & 1347 & 0.2 \\
\hline 41 & (Z)-Isogeranic acid & 1360 & 1365 & 0.6 \\
\hline 42 & Neryl acetate & 1362 & 1362 & 0.9 \\
\hline 43 & $\alpha$-Copaene & 1377 & 1377 & 0.1 \\
\hline 44 & Geranyl acetate & 1381 & 1381 & 0.4 \\
\hline 45 & Methyl eugenol & 1400 & 1404 & 0.7 \\
\hline 46 & $\alpha$-Gurjunene & 1412 & 1410 & 0.1 \\
\hline 47 & $p$-Cymene-7-ol acetate & 1420 & 1423 & 0.2 \\
\hline 48 & Aromadendrene & 1460 & 1461 & 0.3 \\
\hline 49 & Neryl isobutyrate & 1490 & 1484 & 1.6 \\
\hline 50 & 1-Pentadecene & 1492 & 1490 & 0.5 \\
\hline 51 & $\alpha$-Muurolene & 1502 & 1499 & 0.1 \\
\hline 52 & $\gamma$-Cadinene & 1518 & 1514 & 0.2 \\
\hline 53 & $\delta$-Cadinene & 1528 & 1524 & 0.6 \\
\hline 54 & Calamenene & 1538 & 1543 & 0.2 \\
\hline 55 & cis-Sesquisabinene hydrate & 1562 & 1560 & 1.2 \\
\hline 56 & $\alpha$-Copaene-8-alpha-ol & 1569 & 1555 & 0.3 \\
\hline 57 & Neryl-2-methyl butyrate & 1577 & 1570 & 0.3 \\
\hline 58 & $\alpha$-Hummulene epoxide II & 1606 & 1606 & 0.2 \\
\hline 59 & Juneol & 1610 & 1610 & 0.4 \\
\hline 60 & 1-epi-Cabenol & 1628 & 1629 & 0.2 \\
\hline 61 & 10-epi- $\alpha$-Muurolol & 1642 & 1641 & 0.5 \\
\hline 62 & 10-epi-Italicene-12-ol & 1647 & 1645 & 0.4 \\
\hline 63 & Italicene-12-ol & 1661 & 1662 & 0.7 \\
\hline 64 & Cadina-4,10(14)-dien-8- $\beta$-ol & 1669 & 1675 & 0.1 \\
\hline 65 & $(Z)$-Nuciferal & 1674 & 1675 & 1.3 \\
\hline 66 & Cadina-4,10(14)-dien-8- $\alpha$-ol & 1679 & 1680 & 0.4 \\
\hline 67 & Cadina-1(10),4-dien-8- $\alpha$-ol & 1689 & 1690 & 0.3 \\
\hline 68 & $(E)$-Nuciferal & 1698 & 1701 & 3.4 \\
\hline 69 & (Z)-Nuciferal & 1706 & 1705 & 0.6 \\
\hline 70 & (Z)- $\gamma$-Curcumen-12-ol & 1713 & 1711 & 1.9 \\
\hline 71 & (E)-Nuciferol & 1717 & 1715 & 5.2 \\
\hline 72 & (E)- $\gamma$-Curcumen-12-ol & 1730 & 1733 & 0.9 \\
\hline 73 & (Z)- $\gamma$-Curcumen-12-yl formate & 1748 & 1746 & 0.2 \\
\hline 74 & 10-epi-Italicene-12-yl acetate & 1766 & 1765 & 0.9 \\
\hline 75 & (E)-Nuciferyl formate & 1781 & 1777 & 0.2 \\
\hline 76 & (Z)-Nuciferal acetate & 1795 & 1793 & 0.2 \\
\hline 77 & $(Z)$ - $\gamma$-Curcumen-12-yl acetate & 1803 & 1808 & 1.4 \\
\hline 78 & Shiromool & 1810 & 1810 & 5.1 \\
\hline 79 & Hexahydrofarnesyl acetone & 1843 & 1835 & 0.1 \\
\hline 80 & 10-epi-Italicen-12-yl isobutyrate & 1894 & 1895 & 0.4 \\
\hline 81 & Italicene-12-yl isobutyrate & 1914 & 1910 & 0.2 \\
\hline 82 & (Z)- $\gamma$-Curcumen-12-yl isobutyrate & 1938 & 1934 & 0.6 \\
\hline 83 & (E)-Nuciferyl isobutyrate & 1987 & 1975 & 0.1 \\
\hline 84 & 10-epi-Italicen-12-yl isovalerate & 1994 & 1895 & 0.1 \\
\hline 85 & (Z)-Nuciferyl-2-methyl butyrate & 2022 & 2025 & 0.4 \\
\hline 86 & (Z)-Nuciferyl isovalerate & 2034 & 2030 & 0.5 \\
\hline 87 & (E)-Nuciferyl isovalerate & 2048 & 2075 & 0.9 \\
\hline 88 & (E)-Nuciferyl-2-methyl butyrate & 2052 & 2080 & 1.9 \\
\hline \multicolumn{5}{|c|}{ Group components } \\
\hline \multicolumn{5}{|c|}{ Hydrocarbons } \\
\hline & Alkanes, alkenes, alkynes & & & 0.5 \\
\hline & Alcohols & & & 0.2 \\
\hline & Aldehyde & & & 0.4 \\
\hline & Terpenoids & & & \\
\hline & Monoterpene hydrocarbons & & & 5.2 \\
\hline
\end{tabular}




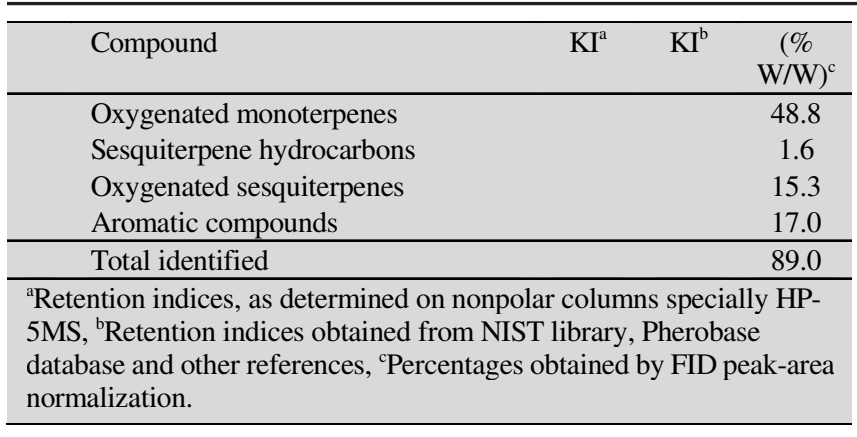

The antimicrobial activity of the oil are shown in Table2. The oil has shown maximum zone of inhibition against Candida albicans $(23 \pm 1.2 \mathrm{~mm})$ with a value higher than that of fluconazol $(18.0 \pm 0.3 \mathrm{~mm})$. Previous studies showed that terpene alcohols are well-known antimicrobial compounds isolated from different plant species ${ }^{32}$. The moderate antimicrobial activity of $P$. gnaphalodes oil could be associated with terpene alcohols. In similar research, the composition of the essential oils obtained by hydrodistillation from the different parts of $P$. arabica from Tunisia at full flowering stage were analyzed by GC/MS ${ }^{22}$. The principal components of flowers essential oil were $\gamma$-cadinene $(11.75 \%), \delta$-cadinene $(9.55 \%)$, $\alpha$-cadinol (8.59\%) while thymol (15.22\%), $\delta$-cadinene $(9.12$ $\%)$, tau-cadinol $(6.65 \%)$ constituted the major components of stems essential oil. The roots were mainly composed of three constituents non identified, $\alpha$-cadinol (2.9\%) and thymol $(2.45 \%)$. The essential oils were tested against Fusarium solani, F. oxysporum, F. oxysporum, Phytophtora cactorum, Alternaria solani and Rhizoctonia solani. The results obtained of antimicrobial activities showed that the essential oils could be considered as natural fungicide agents. Likewise, the composition of the volatile oil constituent from $P$. odora roots has been analyzed by GC/MS ${ }^{23}$. Twenty-seven components were identified, being thymol $(47.83 \%)$ and its derivative isobutyrate $(30.05 \%)$ the main constituents in the oil. Furthermore, the oil was tested against seven bacteria at different concentrations. A strong antibacterial activity was observed against Streptococcus C, Bacillus cereus, Enterococcus faecalis and Pseudomonas vulgaris. In each case. The activity of essential oil was higher than those of the standard antibiotic.

TABLE-2

ANTIMICROBIAL ACTIVITY OF Pulicaria gnaphalodes OIL AND ANTIBUTICS AGAINST STANDARD MICROORGANISMS

\begin{tabular}{ccccc}
\hline Microorganisms & \multicolumn{4}{c}{ Inhibition zone (mm) } \\
\cline { 2 - 5 } & Oil & AMP & GEN & FLU \\
\hline $\begin{array}{c}\text { Escherichia coli } \\
\text { (ATCC 1399) }\end{array}$ & NI & NI & $25.0 \pm 0.3$ & ND \\
$\begin{array}{c}\text { Staphylococcus aureus } \\
\text { (ATCC 1431) }\end{array}$ & $22 \pm 0.7$ & NI & $25.0 \pm 0.2$ & ND \\
$\begin{array}{c}\text { Candida albicans } \\
\text { (ATCC 5027) }\end{array}$ & $23 \pm 1.2$ & ND & ND & $18.0 \pm 0.3$ \\
\hline
\end{tabular}

NI: no inhibition, ND: not determined, AMP: ampicillin, GEN: gentamycin, FLU: fluconazol, Values are means of three replications \pm SD

The antioxidant properties of the $P$. gnaphalodes essential oil measured by DPPH and $\beta$-carotene bleaching assays are presented in Fig. 1. When compared to a standard antioxidant agent, i.e. Trolox, it was found that the oil strongly reduced the concentration of DPPH free radical $(36.0 \pm 1.3 \%)$, with an efficacy higher than that of Trolox $(33.0 \pm 0.5 \%)$. Also, the oil had high inhibition against BHD standard in $\beta$-carotene bleaching test (Fig. 1). This result together with the oil composition may suggest that antioxidant activities of the oils are likely attributable to its principle compounds and phenolic compounds $^{30}$. Phenolic compounds such as thymol show potent antioxidant and DPPH radical scavenging activities ${ }^{33}$. The weak antioxidant activities of the non-phenolic components were also supported by other studies on essential ${ }^{34}$.

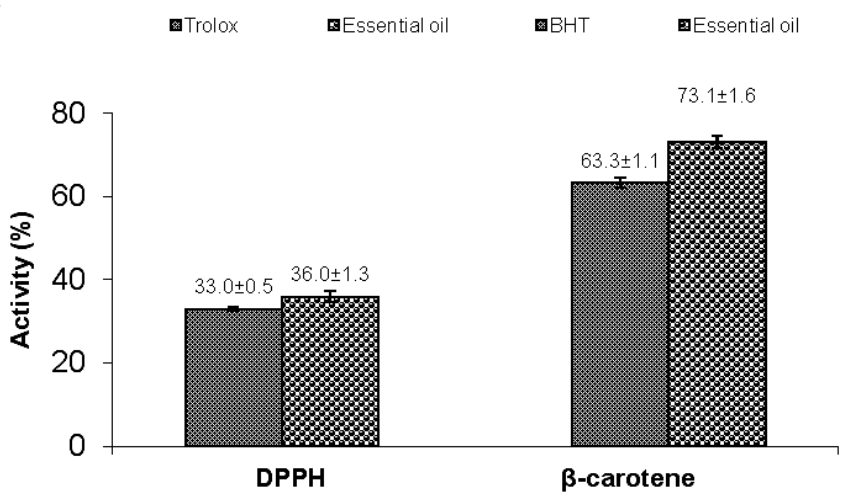

Fig. 1. Free radical-scavenging and antioxidant activities of Pulicaria gnaphalodes essential oil in comparison with those of the references

\section{Conclusion}

We have identified 88 constituents from $P$. gnaphalodes essential oil. The significant antimicrobial activity of $P$. gnaphalodes oil could be associated with main components especially alcohol terpenes. Also, strong antioxidant activities of the oil may be due to the presence of phenolic compounds such as thymol used for traditional applications. Therefore, $P$. gnaphalodes can be used as medicinal plant in traditional applications because it has compounds with potent antimicrobial and antioxidant activities.

\section{ACKNOWLEDGEMENTS}

The authors are grateful to Prof. V. Mozaffarian (Research Institute of Forests and Rangelands, Tehran, Iran) for botanical identi-fication.

\section{REFERENCES}

1. H.M.G. Al-Hazimi and H.Z. Al-Khathlan, J. Chem. Soc. Pak., 14, 233 (1992).

2. V. Mozaffarian, A Dictionary of Iranian Plant Names, Farhang Moaser Publishers, Tehran, Iran, (1996).

3. L.L. Liu, J.L. Yang and Y.P. Shi, Chem. Biodivers., 7, 327 (2010).

4. M. Ravandeh, J. Valizadeh, M. Noroozifar and M. Khorasani-Motlagh, J. Med. Plants Res., 5, 2035 (2011).

5. M. Stavri, K.T. Mathew, A. Gordon, D. Steven, R. Shnyder, A. Falconer and S. Gibbons, Phytochemistry, 69, 1915 (2008).

6. B. Nickavar, G.R. Amin and P. Ghavamian, Iran. J. Pharm. Res., 1, 31 (2002).

7. H.H. El-Kamali and S.A. Mahjoub, Ethnobotan. Leaflets, 13, 722 (2009).

8. A.A. Alghaithy, H.A. El-Beshbishy, A.B. AbdelNaim, A.A. Nagy and E.M. Abdel-Sattar, Toxicol. Ind. Health, 27, 899 (2011).

9. H. Bakthira, N.A.A. Ali, N. Arnold, A. Teichert and L. Wessjohann, Afr. J. Tradit. Comp. Altern. Med., 8, 296 (2011). 
10. A. Rustaiyan, E. Simozar, A. Ahmadi, M. Grenz and F. Bohlmann, Phytochemistry, 20, 2772 (1981).

11. E. Wollenweber and A. Rustaiyan, Biochem. Syst. Ecol., 19, 673 (1991).

12. M.S. Ali, M. Jahangir, M. Saleem and V.U. Ahmad, Nat. Prod. Sci., 5, 134 (1999).

13. M.S. Ali, M. Jahangir, S.S. Uzair, A.W. Erian and R.B. Tareen, Nat. Prod. Lett., 16, 179 (2002).

14. K.A. Eshbakova, Plants-Intermed. J. Phytomed. Related Ind., 3, 161 (2011).

15. H. Mumivand, A.R. Rustaii, K. Jahanbin and D. Dastan, J. Essent. Oil Bearing Plants, 13, 717 (2010).

16. A. Basta, O. Tzakou, M. Couladis and M. Pavlovic, J. Essent. Oil Res., 19, 333 (2007)

17. P. Weyerstahl, H.C. Wahlburg, H. Marschall and A. Rustaiyan, Liebigs. Ann. Chem., 1993, 1117 (1993).

18. R. Weyerstahl, H. Marschall, C. Christiansen, A. Rustaiyan and F. Mirdjalili, Flav. Fragr. J., 14, 121 (1999).

19. F. Hichri, J. Chria, S. Hammami, H.B. Jannet and Z. Mighri, J. Soc. Chim. Tunisie, 11, 77 (2009)

20. F. Nematollahi, A. Rustaiyan, K. Larijani, M. Nadimi and S. Masoudi, J. Essent. Oil Res., 18, 339 (2006).

21. N.E. Abed, F. Harzallah-Skhiri and N. Boughalleb, Agric. Segment, 1, 1530 (2010).
22. M.A. Yousuf, A. Bashir, K. Veres, A. Dobos, G. Nagy, I. Mathe and G. Blunden, J. Essent. Oil Res., 13, 454 (2001).

23. F.E. Hanbali, M. Akssira, A. Ezoubeiri, C.E. Gadhi, F. Mellouki, A. Benherraf, A.M. Blazquez and H. Boira, J. Ethnopharmacol., 99, 399 (2005).

24. http://webbook.nist.gov/

25. http://www.pherobase.com/database/kovats/kovats-index.php

26. H. Van Den Dool and P.D. Kratz, J. Chromatogr. A, 11, 463 (1963).

27. C.M. Collins and P.M. Lyne, Microbiological Methods, London, Butterworths (1987).

28. P.R. Murray, E.J. Baron, M.A. Pfaller, F.C. Tenover and R.H. Yolke, Manual of Clinical Microbiology, Washington, DC, ASM, edn. 7 (1995).

29. M. Burits and F. Bucar, Phytother. Res., 14, 323 (2000).

30. M.S. Taga, E.E. Miller and D.E. Pratt, J. Am. Oil Chem. Soc., 61, 928 (1984).

31. H.S. Choi, H.S. Song, H. Ukeda and M. Sawamura, J. Agric. Food Chem., 48, 4156 (2000).

32. Y. Inoue, A. Shiraishi, T. Hada, K. Hirose, H. Hamashima and J. Shimada, FEMS Microbiol. Lett., 237, 325 (2004).

33. G. Ruberto and M.T. Baratta, Food Chem., 69, 167 (2000).

34. D. Lopez-lutz, D.S. Alviano, C.S. Alviano and P.P. Kolodziejczyk, Phytochemistry, 69, 732 (2008) 